\title{
Intraductal papillary mucinous neoplasm of the extrahepatic biliary duct: Report of a case
}

\section{Ekstrahepatik safra kanalının intraduktal papiller müsinöz neoplazisi: Olgu sunumu}

*Volkan Öter ${ }^{1}$, İlter Özer ${ }^{1}$, Murat Ulaş ${ }^{1}$, Tahsin Dalgıç ${ }^{1}$, Tülay Keklik², Erdal Birol Bostanc1 ${ }^{1}$

\author{
${ }^{1}$ Department of Gastroenterological Surgery, Turkiye Yuksek Ihtisas Teaching and Research Hospital, Ankara, Turkey \\ ${ }^{2}$ Department of Pathology, Turkiye Yuksek Ihtisas Teaching and Research Hospital, Ankara, Turkey \\ Corresponding author: Dr. Volkan Öter, Gastroenteroloji Cerrahisi Anabilim Dalı, Türkiye Yüksek İhtisas Eğitim ve \\ Araştırma Hastanesi, TR-06230 Ankara, Türkiye \\ E-mail: otervolkan@gmail.com \\ Received/Accepted: November 19, 2014/May 11, 2015
}

Conflict of interest: There is not a conflict of interest.

\section{SUMMARY}

Malignant biliary tract intraductal papillary mucinous neoplasms (BT-IPMN) is a relatively rare disease. A 47-year-old male patient presented with pain and sensitivity on the right upper quadrant of abdomen. Abdominal tomography revealed marked dilatation of the intra-hepatic and extrahepatic bile ducts and polypoid intraluminal mass in the distal extrahepatic bile duct. ERCP was performed and the distal common bile duct brush biopsy was taken. Biopsy revealed IPMN with high grade dysplasia (intraductal papillary mucinous carcinoma in-situ). Patient underwent resection of the extrahepatic bile duct with Roux-en-Y hepaticojejunostomy. Patient was discharged on postoperative seventh day. He has been regularly followed at our outpatient department with no evidence of recurrence. A very rare variant of bile duct carcinoma is distal extrahepatic bile duct papillary neoplasm. Papillary cholangiocarcinoma is believed to show a better prognosis if early detected. It is important to make a precise diagnosis of BT-IPMN and to perform complete surgical resection.

Keywords: Intraductal papillary mucinous neoplasm, biliary tract, papillary, mucinous

ÖZET

Safra kanalının malign intraduktal papiller müsinöz neoplazisi(IPMN) nadir görülen bir hastalıktır. 47 yaşında erkek hasta sağ üst kadran ağrısı ve hassasiyet ile başvurdu. Karın tomografisinde intrahepatik ve ekstrahepatik safra yollarında belirgin genişleme ve ekstrahepatik kanal distalinde lümen içerisinde kitle saptandı. ERCP yapılarak distal ana safra kanalından fırça biyopsi alındı. Biyopsi sonucunda şiddetli displazi odakları içeren IPMN (karsinoma in-situ) saptandı. Hasta ameliyata alınarak ekstrahepatik safra kanalı eksizyonu ve Roux-en-Y hepatikojejunostomi uyguland1. Ameliyat sonrası 7. gün hasta taburcu edildi. Hasta polikliniğimizde düzenli aralıklarla takip edilmekte olup hastalığında tekrarlama gözlenmemiştir. Distal ekstrahepatik safra kanalı kanserleri arasında papiller neoplazi çok nadir görülen bir türdür. Eğer erken saptanırsa iyi prognoz göstereceğine inanılmaktadır. Safra yolu İPMN de erken tanı ve tam cerrahi eksizyon çok önemlidir.

Anahtar sözcükler: İntraduktal papiller müsinöz neoplazi, safra kanalı, papiller, müsinöz 


\section{INTRODUCTION}

Biliary tract intraductal papillary mucinous neoplasms (BT-IPMN) have been increasingly recognized as unique biliary neoplasms characterized by mucinsecreting papillary and/or cystic lesions of the intra-and extra-hepatic bile ducts ${ }^{1,2}$. Malignant BT-IPMN is a relatively rare disease, which accounts for $2.9 \%$ to $8.9 \%$ of cholangiocarcinoma ${ }^{3}$. Papillary cholangiocarcinoma is believed to show a better clinical course than non-papillary cholangiocarcinoma $^{4,} 5$ as malignant intraductal papillary mucinous neoplasm of the pancreas (IPMN-P) has a better prognosis than pancreatic ductal adenocarcinoma. Therefore, it is important to make a precise diagnosis of BT-IPMN and to perform complete surgical resection. We herein report a case of an intraductal papillary mucinous cholangiocarcinoma successfully treated by extrahepatic bile duct resection.

\section{CASE REPORT}

A 47-year-old male patient presented with pain and sensitivity on the epigastrium and right upper quadrant. He had no other symptoms or medical history of liver disease. He did not smoke and was a social drinker. On physical examination, he was a well-appearing, non-jaundiced male and no evidence of hepatosplenomegally, lymphadenopathy, or masses; beside this, there was no significant finding including vital sign. Initial laboratory values included WBC of $8.300 / \mu \mathrm{L}$, albumin of 4.7 $\mathrm{g} / \mathrm{dL}$, total bilirubin of $0.78 \mathrm{mg} / \mathrm{dL}$, direct bilirubin of $0.47 \mathrm{mg} / \mathrm{dL}$, AST/ALT of $581 / 840 \mathrm{IU} / \mathrm{L}$, alkaline phosphatase of 178 $\mathrm{IU} / \mathrm{L}, \gamma-\mathrm{GTP}$ of $887 \mathrm{IU} / \mathrm{L}, \alpha-\mathrm{FP}$ of 0.5 $\mathrm{ng} / \mathrm{mL}$, CEA of $0.5 \mathrm{ng} / \mathrm{mL}$, CA $19-9$ of $3.03 \mathrm{U} / \mathrm{mL}$. A dilatation and intraluminal hypoechoic lesion of the extrahepatic bile duct which was detected in abdominal ultrasonography (US) (Figure 1). Abdominal tomography revealed marked dilatation of the intra-hepatic and extrahepatic bile duct and polypoid intraluminal mass in the distal extrahepatic bile duct (Figure 2).

ERCP and endoscopic sphincterotomy performed and the distal common bile duct brush biyopsy was taken for cytologic examination. Biopsy of the lesion revealed
IPMN with high grade dysplasia (intraductal papillary mucinous carcinoma in-situ), (Figure 3). These findings suggested BT-IPMN with malignancy potential and prompted us to plan a curative extrahepatic bile duct resection. Neither ascites nor peritoneal metastatic nodule was detected during initial intraperitoneal exploration. Patient underwent the resection of the extrahepatic bile duct with Roux-en-Y hepaticojejunostomy.

The histopathological examination for the resected specimen yielded the final diagnosis of mucin-producing oncocytic intraductal papillary carcinoma of the bile duct (Figure 4). Resection margins of the proximal bile duct and hepatic parenchyma were free of tumor cell. Dissected regional lymph nodes was confirmed to be without tumor cells. The patient showed no postoperative complication and was discharged on postoperative seventh day. $\mathrm{He}$ has been regularly followed at outpatient department with no evidence of recurrence more than three years.

\section{DISCUSSION}

Bile duct carcinoma usually develops through a multistep process involving one of two separate precursor pathways. The initial lesion is flat biliary dysplasia (biliary intraepithelial neoplasia) found in both the intra-and extrahepatic biliary tree and graded in severity as 1 (mild dysplasia), 2 (moderate dysplasia), or 3 (severe dysplasia/carcinoma in situ) ${ }^{6}$.

A less common variant of bile duct carcinoma is the intraductal papillary neoplasm characterized by exophytic proliferation of biliary epithelium on fibrovascular stalks within the bile duct lumen, sometimes associated with mucin hypersecretion and cystic dilatation of the affected bile ducts ${ }^{7}$. These tumors can be entirely intraductal or they can have an associated invasive carcinoma component, and although many different terms have been used for this spectrum of neoplasms, recently they have been collectively termed BT-IPMN.

In the present study, $12 \%$ of resected bile duct carcinomas met the pathologic definition of BT-IPMN ${ }^{8}$. Previous reports 
found the incidence of BT-IPMN among all bile duct carcinomas to range from $7 \%$ to $38 \%$, 10 .

The most important factors in the etiology of intraductal papillary neoplasia are stone, infection, pancreatic injury, and biliary hyperplasia on the base $e^{6,11,12}$.

According to previous reports BT-IPMN has been characterized clinically by common presenting symptoms of abdominal discomfort, jaundice, macroscopic mucin hypersecretion and elevated pre-operative levels of serum total bilirubin and alkaline phosphatase ${ }^{2,}$,, 13 . our patient had only pain and sensitivity on the epigastrium and right upper quadrant of his abdomen.

BT-IPMN is subdivided on the basis of histology and mucin gene protein (MUC1, MUC2, and MUC5) expression into two to four subtypes; columnar and cuboidal types $^{14}$; pancreatobiliary, intestinal, and/or gastric, and/or oncocytic types ${ }^{12,15,16}$.

Accumulated radiologic and endoscopic information on BT-IPMN makes a diagnosis not so difficult. Specific findings of CT or US and cholangiograms, such as marked biliary dilatation and amorphous filling defects within the dilated bile ducts, could raise suspicion and simultaneous endoscopic demonstration of mucobilia is specific for the diagnosis of BT-IPMN ${ }^{6,17}$, 18 After radiologic findings, we could highly suspect BT-IPMN and then ERCP and endoscopic sphincterotomy performed and the distal common bile duct brush cytology taken for biopsy. Biopsy of the lesion was IPMN with high grade dysplasia (intraductal papillary mucinous carcinoma in-situ). Because BT-IPMN is considered to have a favorable prognosis after complete surgical resection, an aggressive surgery deserves to be recommended regardless of tumor size and extent $^{4,19}$.

In conclusion; a very less common variant of bile duct carcinoma is the intraductal papillary neoplasm. Papillary cholangiocarcinoma is believed to show a better prognosis if early detected. So that it is important to make a precise diagnosis of BT-IPMN and to perform complete surgical resection. We herein report a case of an extra-hepatic duct papillary mucinous cholangiocarcinoma successfully treated by resection of the extra-hepatic bile duct with Roux-en-Y hepaticojejunostomy.

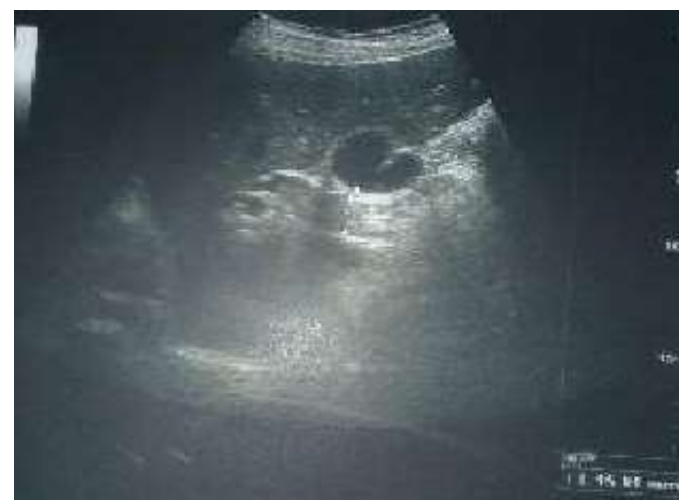

Figure 1. Dilatation and intraluminal hypoechoic lesion of the extrahepatic bile duct which was detected in abdominal ultrasonography.

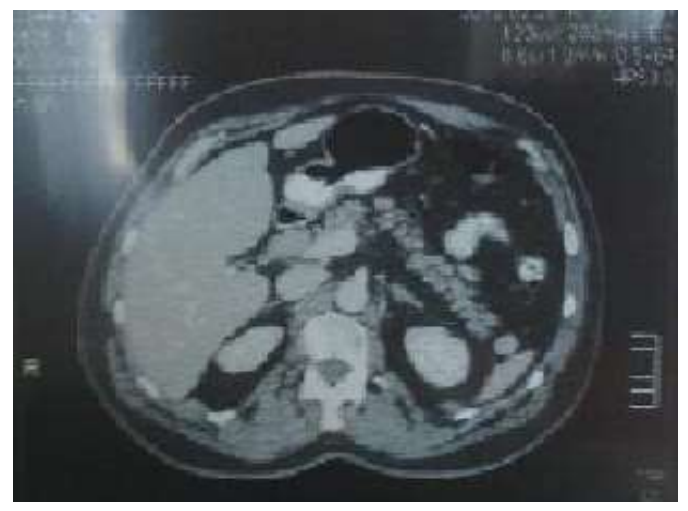

Figure 2. Abdominal tomography revealed marked dilatation of extra-hepatic bile duct and polypoid intraluminal mass in the distal extrahepatic bile duct.

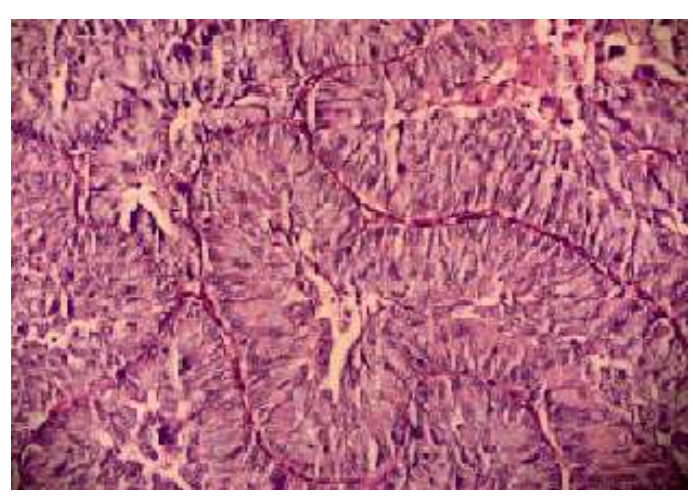

Figure 3. High power view of mucinous cells. (Slide is prepared from the resection specimen), (H\&E 40X). 


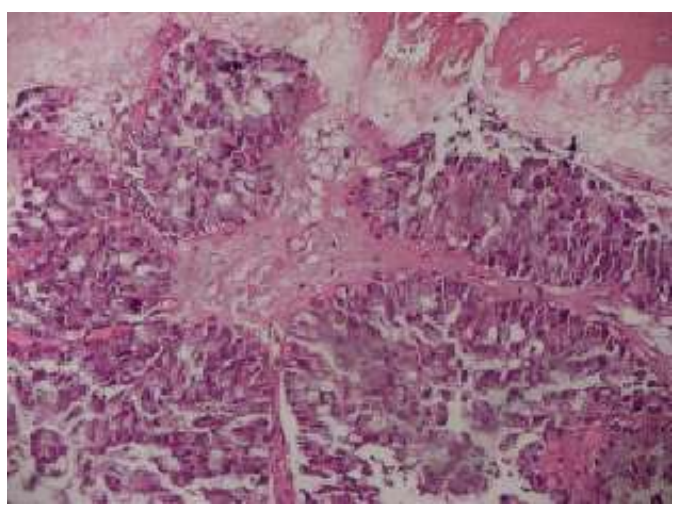

Figure 4. Papillary projection lined by tall, columnar mucinous epithelium (slide is prapered from the biyopsi specimen), (H\&E 10X).

\section{REFERENCES}

1. Kim HJ, Kim MH, Lee SK, Yoo KS, Park ET, Lim BC. Mucinhypersecreting bile duct tumor characterized by a striking homology with an intraductal papillary mucinous tumor (IPMT) of the pancreas. Endoscopy 2000; 32: 389-93.

2. Zen Y, Fujii T, Itatsu K, Nakamura $\mathrm{K}$, Minato H, Kasashima S. Biliary papillary tumors share pathological features with intraductal papillary mucinous neoplasm of the pancreas. Hepatology 2006; 44: 1333-43.

3. Suzuki A, Suzuki S, Sakaguchi T, Fukumoto K, Ota S, Inaba K. A case of mucin producing cholangiocarcinoma arising from the right hepatic duct. (In Japanese with English abstract.) Jpn J Gastroenterol Surg 2008; 41: 206-11.

4. Suh KS, Roh HR, Koh YT, Lee KU, Park YH, Kim SW. Clinicopathologic features of the intraductal growth type of peripheral cholangiocarcinoma. Hepatology 2000; 31: 12-7.

5. Tajima Y, Kuroki T, Fukuda K, Tsuneoka N, Furui J, Kanematsu T. An intraductal papillary component is associated with prolonged survival after hepatic resection for intrahepatic cholangiocarcinoma. Br J Surg 2004, 91: 99104.

6. Chen TC, Nakanuma Y, Zen Y, Chan MF, JanYY, Yeh TS. Intra- ductal papillary neoplasia of the liver associated with hepatolithiasis. Hepatology 2001; 34: 651-8.

7. Nakanuma $Y$, Zen $Y$, Harada K, Ikeda H, Sato Y, Uehara T. Tumorigenesis and phenotypic characteristics of mucin-producing bile duct tumors: An immunohistochemical approach. J Hepatobiliary Pancreat Sci 2010; 17: 211-22.

8. Bosman FT, Carneiro F, Hruban $\mathrm{RH}$, eds. WHO Classification of Tumours of the Digestive System. World Health Organization Classification of Tumours. Lyon, France: IARC 2010.

9. Barton JG, Barrett DA, Maricevich MA, Schnelldorfer T, Wood CM, Smyrk TC. Intraductal papillary mucinous neoplasm of the biliary tract: A real disease? HPB (Oxford) 2009; 11: 684-91.

10. Yeh CN, Jan YY, Yeh TS, Hwang TL, Chen MF. Hepatic resection of the intraductal papillary type of peripheral cholangiocarcinoma. Ann Surg Oncol 2004; 11: 606-11.

11. Güllüoğlu MG, Ozden I, Poyanlı A, Cevikbas U, Arioglu O. Intraductal growth-type mucinproducing peripheral cholangiocarcinoma associated with biliary papillomatosis. Ann Diagn Pathol 2007; 11: 34-8.

12. Zen Y, Sasaki M, Fujii T, Chen TC, Chen MF, Yeh TS. Different expression patterns of mucin core proteins and cytokeratins during intrahepatic cholangiocarcinogenesis from biliary intraepithelial neoplasia and intraductal papillary neoplasm of the bile ductan immunohistochemical study of 110 cases of hepatolithiasis. J Hepatol 2006; 44: 350-8.

13. Rocha FG, Lee H, Katabi N, Dematteo RP, Fong Y, D'Angelica MI. Intraductal papillary neoplasm of the bile duct: A biliary equivalent to intraductal papillary mucinous neoplasm of the pancreas? Hepatology 2012; 56: 1352-6.

14. Shibahara H, Tamada S, Goto M, Oda K, Nagino M, Nagasaka T. Pathologic features of mucin- 
producing bile duct tumors: Two histopathologic categories as counterparts of pancreatic intraductal papillary-mucinous neoplasms. Am J Surg Pathol 2004; 28: 32738.

15. Kloppel G, Kosmahl M. Is the intraductal papillary mucinous neoplasia of the biliary tract a counterpart of pancreatic papillary mucinous neoplasm? J Hepatol 2006; 44: 249-50.

16. Ji Y, Fan J, Zhou J, Wang BS, Liu $\mathrm{HB}, \mathrm{Wu} \mathrm{ZW}$, Tan YS. Intraductal papillary neoplasms of bile duct. A distinct entity like its counterpart in pancreas. Histol Histopathol 2008; 23: 41-50.

17. Chen MF, Jan YY, Chen TC. Clinical studies of mucin-producing cholangiocellular carcinoma: A study of 22 histopathologyproven cases. Ann Surg 1998; 227: 63-9.

18. Yeh TS, Tseng JH, Chen TC, Liu NJ, Chiu CT, Jan YY. Characterization of intrahepatic cholangiocarcinoma of the intraductal growth-type and its precursor lesions. Hepatology 2005; 42:65764.

19. Yeh TS, Tseng JH, Chiu CT, Liu NJ, Chen TC, Jan YY. Cholangiographic spectrum of intraductal papillary mucinous neoplasm of the bile ducts. Ann Surg 2006; 244: 248-53. 